\title{
ABBREVIATIONS, SYMBOLS, AND DIACRITICAL MARKS
}

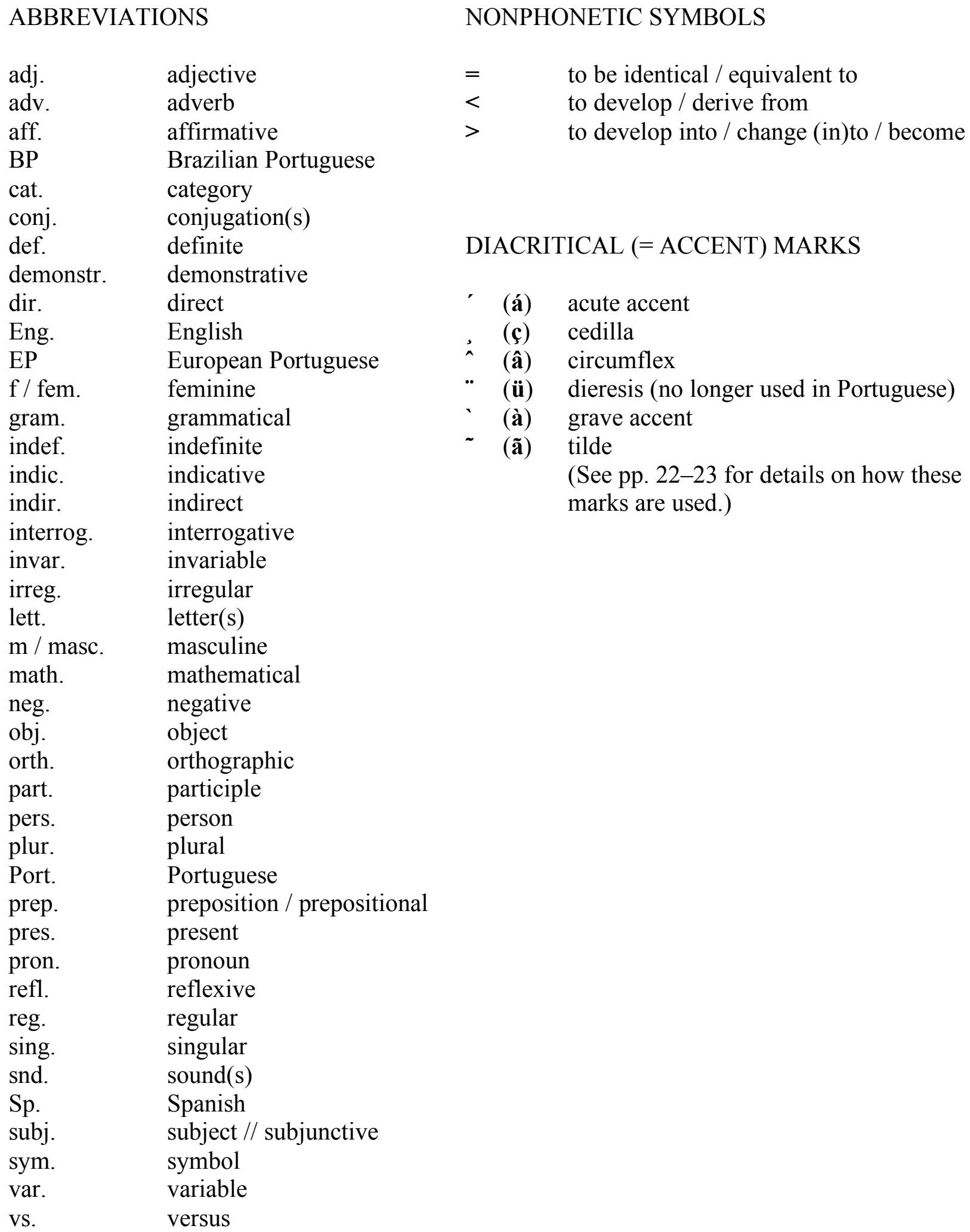

